\title{
Integrating web 2.0 technology in ESL classroom: A review on the benefits and barriers
}

\author{
Mohd Shakir Azfar Abdul Halim ${ }^{1,2}$, Harwati Hashim ${ }^{2}$ \\ ${ }^{1}$ Sekolah Kebangsaan Ampangan \\ ${ }^{2}$ Universiti Kebangsaan Malaysia
}

\section{Article Info \\ Article history: \\ Received Jun $10^{\text {th }}, 2019$ \\ Revised Jun $25^{\text {th }}, 2019$ \\ Accepted Jul 15 ${ }^{\text {th }}, 2019$}

\section{Keyword:}

Web 2.0

Social networks

English as a Second Language

ESL classroom

Language teaching and learning

\section{Corresponding Author:}

Harwati Hashim

Universiti Kebangsaan Malaysia

Email: harwati@ukm.edu.my

\begin{abstract}
In this immensely growing information and communication technology (ICT) era, technology has been a subject matter that is not "alien" any more in all fields, including the education field. Nowadays, integrating technology in teaching and learning process is seen vital and essential in its way to offer a more meaningful learning to the learners, and to produce high-quality human capital equipped with the 21st century skills. In English as a Second Language (ESL) teaching and learning particularly, there are many ways educators have used to ensure that ESL learners could benefit from incorporating technology in ESL classroom including through the use of Web 2.0 technology. This paper aims to review the benefits and barriers of integrating Web 2.0 technology in ESL classroom. This paper uses a number of journal articles and conference proceedings in aiding to find the related data. Thus, it is concluded that although integrating Web 2.0 technology in ESL classroom does come with its apparent barriers, the benefits of it towards ESL teaching and learning process and ESL learners are also evident and will be further discussed in the findings.
\end{abstract}

(C) 2018 The Authors. Published by Redwhitepress.

This is an open access article under the CC BY-NC-SA license

(https://creativecommons.org/licenses/by-nc-sa/4.0/

\section{Introduction}

Currently, in this rapidly developing era of the ICT that we live in, the word "technology" itself has been a topic that is not foreign anymore, and has emerged as a very familiar subject matter that has also been researched for many times, for its abilities in improving the teaching and learning of ESL. Nowadays, educators could hear almost every day that the need to create high-quality human capital that is accustomed with the 21st century skills is more imperative than ever (Jemima, Melor \& Jamal, 2017). In Malaysia, the Ministry of Education (MOE) has set up a set of skills and competencies in the Malaysian Education Blueprint 2013-2025 that are aligned with the National Education Philosophy. Those skills would prepare our students with the necessities required to meet the challenges of a world that is being transformed by the applications of science, technology, engineering and mathematics (STEM). Furthermore, the new curriculum also emphasises higher-order thinking skills (HOTS) such as analysing, critical thinking, hypothesising and decision making.

Other than that, according to Güzer and Caner (2014), the fast movement of the Internet affected the "popularity of distance education" (p. 4596) and has caused new terms like online learning, e-learning or webbased learning to emerge. Furthermore, the utilisation of technology-based activities in teaching and learning is continually practised by many educators, and researches have shown that it substantially aids students' learning (Thang et al. 2013). There are many sorts of current technology that we, as English educators, can 
integrate in our teaching and learning that can vastly benefit the learners, and one of it is through the use of Web 2.0 in the ESL classroom.

Next, in the present landscape of technological and social change, significant transformations are in motion in terms of how we live and work. Harwati et al. (2017) claimed that technology remains to influence learners' lives inside and outside the classrooms to an extent that they utilise technology to improve their learning experiences and processes. Nowadays, Web 2.0 technologies have turned out to be a pertinent component or aspect of our daily lives in this 21st century era we are living in (McBride, 2009). As Wang and Vasquez (2012) pointed out, a lot of people out there currently utilise Web 2.0 technology to "interact, collaborate, network, and entertain through blogs, wikis, as well as social networking tools including Facebook, Twitter, Instagram, LinkedIn and so on" (p. 1) The authors also added that a lot of these people revel in the excitement of instant self-publishing and feel encouraged by their online interactions that are considered dynamic. They also added that for the last ten years, the transition from Web 1.0 to 2.0 has been remarkably outstanding. With the aid of modern ICT knowledge, skills and tools, we form and share information apart from just reading and retrieving them online (Lomicka \& Lord, 2016).Thus, it is evident now that the usage of Web 2.0 has been spreading fast across the globe, and as a significant result of this, Web 2.0 communications have become a crucial and essential part of many learners' daily and academic lives (McBride, 2009). The following sections discuss the definition of Web 2.0 technology and various researches done related to it, the benefits and the barriers of using it in ESL classroom.

\section{Web 2.0: General Overview}

According to O'Reilly (2005), the concept of Web 2.0 developed in 2004 from a session of conference brainstorming, when he was discussing the future of dot-com businesses with other web developers. Thus, it is generally accepted that the term Web 2.0 initially emerged in that first Web 2.0 conference. In the last decade, the definition of Web 2.0 has been produced from different perspectives and by different scholars (Grosseck, 2009) and has remains controversial. Nakamaru (2011), stated that Web 2.0 is a term used to describe "a paradigm shift" (p. 1) in the way we view and utilise the Internet. Warschauer and Grimes (2007) claimed that the term Web 2.0 is defined for not just a new version of existing Web technology, but that it denotes actual "changes in the communicative uses of the underlying Web platform" (p. 2). Other than that, according to Tu, Blocher, and Ntoruru (2008), Web 2.0 is also defined as "a Web technology that aims to enhance creativity, information sharing and collaboration among users" (p. 336). Next, Web 2.0 is also considered as a rather loose notion that describes a set of incredible technologies currently in fast development (Zhang, 2009).

However, although the meanings of Web 2.0 are varied and highly debatable, they do not differ to each other. Based on what and how various scholars have defined it, Web 2.0 generally refers to the web development and design which are from the second generation of development(Wang, 2009) that leads to social use of the Web which allows users to act as a team in creating knowledge, sharing information online and getting actively involved with each other in creating content that facilitates communication. Then, before this, the Web was a place to receive information and entertainment in which users only consumed the content (Nakamaru, 2011). Nowadays, the Web is a platform to not just create, but also share knowledge and information. This means that instead of just downloading information, users can upload them, and instead of just reading information, we can now create them. Thus, the Web itself has been and still is being shaped by those who use it.

\section{Web 2.0 in Education}

Hence, putting all these into consideration, Web 2.0 platforms or tools, for example online discussion boards, forums, blogs, Facebook, Flickr, YouTube, Instagram, Twitter and many more, are viewed to have emerged with a vital role to transform teaching and learning process (Alexander \& Levine, 2008). These tools allow users to communicate and collaborate with one another via social media in a virtual community (Ajjan $\&$ Hartshorne, 2008). Many language teachers and educators have started to try integrating the tools offered by Web 2.0 in the field of second language education, and this has significantly become a trend (McLoughlin \& Lee, 2007). The potential impact of Web 2.0 technologies on language classroom is indeed revolutionary (Sturm, Kennell, McBride, \& Kelly 2009; Warschauer \& Grimes 2007; Wang \& Vasquez 2012). Bosch (2009) added that most Web 2.0 tools like the social networking platforms are utilised to maintain existing networks and develop new ones. This would permit an ongoing rapid network, thus allows participation in various micro-communities, some of which could be educational.

Apart from that, scholars have proven that by developing groups of practice, distance education courses could usually be more successful. Other than that, it could also elevate the levels of online social 
presence between learners (Brady, Holcomb \& Smith, 2010). Encouraging a sense of community is undoubtedly vital, particularly in an online environment in which learners frequently do not get the chances to have sufficient face-to-face interactions with other learners and/or teachers in classroom. Since they enable information sharing, the technologies present in social networking sites provided by the Web 2.0 technology facilitate discussion among online learners, as they have the capability to associate with each other as well as form community in a socially and educationally assembled network.

Furthermore, researches have been and still are being conducted focusing on Web 2.0 technology and language classroom. In instance, Greenhow, Robelia \& Hughes (2009) wrote about how Web 2.0's unique capabilities and youth's proclivities in using it influence the teaching and learning process. In their study, two significant themes were emerged; learner participation and creativity and online identity formation. Next, Ajjan and Hartshorne (2008) conducted a study to investigate a university faculty's awareness of the advantages of Web 2.0 technology to complement classroom-based learning and better comprehend the faculty's decisions to adopt these tools using the decomposed theory of planned behaviour (DTPB) model. In their writing, it was found that the faculty members agreed that Web 2.0 could improve varsity students' learning, their social interaction and their writing skills. Apart from that, Melor et al. (2012) wrote a paper aiming at examining the students' perceptions on the use of Facebook groups in teaching ESL writing. They concluded in their study that Facebook groups could be effective in teaching ESL writing, especially involving the tertiary level students.

Moreover, Manca and Ranieri (2013) wrote a critical review of studies focusing on how Facebook is being used as a technology-enhanced learning environment, with the purpose of discovering how far we interpret its pedagogical potential into practice. Next, Lomicka and Lord (2016) wrote an article which had the aim of examining the theoretical foundations of using social networking in language classroom, and in what ways the tools offered in social networking can be effective in the learning process. Furthermore, Melor, Hadi and Chen Chenzi (2012) wrote a paper that intended to study the benefits and drawbacks of incorporating social networking tools into ESL classroom, particularly in writing lessons, and suggest ways to plan activities by incoporating social networking services (SNSs) into the teaching and learning process. In addition, McLoughlin and Lee (2007) also wrote a paper which aimed to study the affordances of Web 2.0 and social software and the choices as well as the barriers they could provide to educators and learners of the tertiary level. They discussed on how Web 2.0 can be benefited in the tertiary education field by giving suggestions to others too. Apart from that, they also discussed in their paper how the affordances of social software tools can be conceptualised, so that they are associated to process skills and socio-cognitive outcomes.

\section{Benefits of Web 2.0 Technology in ESL Learning}

Based on many past studies, Web 2.0 technology has become a vital and essential aiding tool in the teaching and learning process. Next, studies have also shown that technologies especially the use of ICT, in this instance the Web 2.0 technology, does provide positive impacts towards both the ESL classroom and ESL learners. It has also been claimed that the incorporation of Web 2.0 technology in many second language learning contexts has positively transformed teaching methodology, pedagogy, curriculum design, the conception of language learning, and even the researches in the education field (Sturm et al., 2009; Warschauer \& Grimes 2007; Wang \& Vasquez, 2012).

Melor, Hadi and Chen (2012) pointed out in their writing, which studied the advantages and disadvantages of incorporating social networking tools into ESL learning, particularly in writing lessons, that most learners now are digital natives, hence social networking tools, which is an example of the Web 2.0 technology, engage them by presenting material in a way that is familiar and comfortable for them. The authors also added that learners may be able to receive enough input from social networking tools, so they will enhance students' writing skills. Furthermore, in social networking sites like Blogs and Facebook, teacher's notes can be viewed and read chronologically - which is very "convenient when preparing lessons that build upon previous materials taught in the class" (p.3).

Besides that, Al-Ali (2014) investigated the use of Instagram - a social networking tool in Web 2.0 technology - as a learning tool in language classroom. He claimed in his writing that Instagram can be beneficial in language teaching and learning process, for it provides a myriad of contextualised visual data that can offer support in language classrooms. These supports are particularly expedient because they provide visual elements that can cater to visual learners. Furthermore, incorporating Instagram in language lessons can aid to produce a socially connected community of students, as the tool itself offers room for them to communicate and socialise with each other beyond classroom limitations. This is because that Instagram offers the 'like' and 'comment' functions, which are not taken for granted by Instagram users, which assists the socialisation and communication between users. 
Moreoever, Melor et al. (2012) claimed in their paper; which investigated the language learners' perceptions of using Facebook groups in ESL teaching of writing; that most of their respondents agreed that Facebook groups did help enhance their process of learning writing in ESL lessons. The Facebook groups acted as a tool that helped them in their ESL writing in a way that it aided them in the brainstorming process to organise their ideas and thoughts before the actual writing. Other than that, they also claimed that it helped them to learn new vocabulary from the comments given by their peers. This means that integrating Web 2.0 technology in ESL classroom could also promote peer coaching which could benefit the lower achiever learners to learn the language. Next, the authors also reported that their learners claimed that this intervention of enhancing teaching of ESL writing helped them to make less spelling errors through the spell-check feature offered by the tool itself. The authors stated that "When students were unsure of the spelling of a word, if they were to type it in the comment space, red lines would appear if the spelling is incorrect" (p.4). Therefore, by utilising this particular feature, learners could easily 'right-click' on the word to see the spelling of words that are suggested by the spell-check feature. They also added that this matter is something that writing using paper and pen lacks, and if learners were to come across problems with the correct spelling, it could be tedious for them to find the meaning in the dictionary too.

Other than that, Sadaf, Newby, and Ertmer (2012) studied pre-service teachers' perceptions of using Web 2.0 technology in their future classrooms. The 12 participants in the exploratory qualitative study (i.e., interviews, reflections) were first-year students in a teacher education programme at a large Midwestern university. In addition to the 12 initial participants, 190 students completed an open-ended survey. The results showed that a majority (51\%) were dedicated to Web 2.0 technology as an instructional tool largely because it may increase engagement among students. The pre-service teachers recognised that even though they were proficient users of the technology who feel comfortable of using it, they would require assistance as how to employ its effective use in the classroom. Additionally, Brady, Holcomb and Smith (2012) investigated the use of Ning in graduate online course at a university and the students' perceptions of using the social networking tool in learning process. Majority if the participants have agreed that the social networking sites encouraged more peer-to-peer communication than a traditional face-to-face class. Apart from that, the respondents also claimed that Ning helped in their communication outside of the class as well. Then, it was also found that the learners agreed that the social networking tool used allowed them to reflect and comment on other's work more effectively and efficiently compared to the sessions they had in a traditional classroom.

Moreover, Ajjan and Hartshorne (2008) studied the perceptions of a faculty university in which they collected survey data from the faculty members to investigate their own awareness of technologies and advantages of incorporating Web 2.0 tools in the traditional classroom. Based on their study, it was found that social networks were viewed as a beneficial tool for enhancing students' satisfaction in their learning process. It was also found that the Web 2.0 tool used in the study which was social networking sites could positively impact learners towards their interaction with other learners. Furthermore, Wang and Vasquez (2012) wrote a review of researches that discussed on the advantages of utilising Web 2.0 in second language learning. They concluded that integrating Web 2.0 technology in a language classroom would benefit learners in many ways including improving learners' confidence level in writing, facilitating students to use writing strategies in actual writing, and enhancing students' overall writing skills. Apart from that, they also concluded that incorporating Web 2.0 technology in second language classroom would assist in providing a learning environment that is comfortable, relaxed, collaboration-oriented, and community-based. They also claimed that students' interest and motivation could also be improved, for current learners are more familiar with the use of current advanced technology including mobile phones, social networking sites, social media and many more.

In addition, Suthiwartnarueput and Wasanasomsithi (2012) conducted a study that discovered the consequences of using Facebook as a means to discuss the topics of grammar and writing among EFL students who had a low to medium proficiency levels. They found that it was beneficial to discuss English grammar on Facebook, due the fact that there were apparent positive correlations between the scores that they gained in the grammar and the written works they were provided with. Additionally, the EFL students also showed positive and encouraging attitudes towards employing Facebook as a medium in grammar and writing classrooms. This is because, as an alternative learning tool, Facebook had become a medium in learning that was very convenient and attractive for the users to participate in any discussions held between them and the teacher and other users who had better knowledge in the grammar and writing skills.

Therefore, summing up this section, based on the reviews above, it can be concluded that integrating Web 2.0 technology in ESL classroom does offer various benefits namely:

- Increasing learners' learning engagement; 
- Enhancing learners' writing skills;

- $\quad$ Providing a more comfortable and convenient learning environment;

- $\quad$ Offering visual data as a learning support to aid learning process;

- $\quad$ Enhancing social skills among learners;

- $\quad$ Promotes peer coaching;

- $\quad$ Promotes communication inside and outside classroom;

- $\quad$ Escalate learners' enthusiasm and self-confidence to learn ESL skills.

Nevertheless, regardless of the potential benefits Web 2.0 technology could offer in ESL lessons, concerns have been raised incessantly on the barriers which are considered the disadvantages or drawbacks in integrating Web 2.0 technology in ESL classroom. The following section discusses the barriers that both ESL teachers and learners could be facing in using Web 2.0 technology for learning English language.

\section{Barriers of Using Web 2.0 Technology in ESL Learning}

Although the benefits are evidently varied, there are some barriers that could become the disadvantages or challenges of employing Web 2.0 in ESL classroom. More specifically, the interactive advantages of Web 2.0 technologies may come with a set of associated barriers (Wang \& Vasquez, 2012). According to Melor et al. (2012), the main barrier that teachers may be facing upon integrating Web 2.0 in their classroom is the interruptions by the other features on Facebook which include Facebook chat, gossip groups on Facebook, in-app applications, games, and many more. They also added that because of these distractions, learners might result in spending more time on those features which then causes them not to fully concentrate on their actual tasks on Facebook groups given by their teachers for the purposes of learning writing. Apart from that, Al-Ali (2014) claimed in his research, which studied the use of Instagram as a learning tool in language learning, that using the Web 2.0 tool could be challenging if learners have a certain level of inhibition and reluctance to get involved in the discussion or tasks provided by teachers. He added more that learners later explained that their reluctance to engage in the activities at first was contributed to the fact that it was a first of its kind learning activity, and they were unsure about the kind of posts they were expected or needed to add.

Besides that, Bosch (2009) reported in his article; that investigated the effectiveness of integrating social networking tools like Facebook in teaching and learning; that bandwidth availability could also be a barrier that hinders the effectiveness of using Web 2.0 technology in language classroom. He added that with the impression that having more students on the Web 2.0 platforms (online discussion board, Wiki, EdModo, Facebook et cetera) at any one time, it would dramatically slow down the entire network. Additionally, some campuses put on bandwidth restrictions which refrain students from playing audio or video on some certain sites, although they are with educational purposes. This could also hinder students from using Web 2.0 technology in their learning process. Adding more to this, Melor, Hadi and Chen (2012), claimed that because that some Web 2.0 tools like the social networking sites are mainly intended for entertainment and pleasure purposes on a large degree, hence students could become distracted by the plethora of entertainment features which are totally unrelated to their learning process.

Next, Richard et al. (2008) discussed on some other barriers of integrating Web 2.0 in ESL classroom. He claimed that the lack of technological devices in education institutions, the low level of awareness on available ICT teaching resources among teachers, as well as inadequate theoretical and practical training of the teachers could avert teachers to successfully incorporate technology into teaching and learning environments especially the Web 2.0 technology. Additionally, when the online student-teacher interaction increases, it is more likely that distance students would drop out of class. This is because; demanding learners' interaction just for the sake of interaction may cause completion rates to decrease, for it is challenging for learners to control themselves to study online (Grandzol \& Grandzol, 2010).

Then, resources could also be considered as another barrier that could challenge the effectiveness of integrating Web 2.0 technology in ESL classroom. Without sufficient resources, the incorporation of ICT in classroom may not be meaningfully carried out, despite that all the other conditions are met (Termit \& Ganisha, 2014; Harwati et al., 2017). In addition, it was also found that in a genuine blog environment, learners felt exasperated by their incapability to differentiate between standard and non-standard forms of the target language, which could then eventually affect their language use in other situations (Lee, 2006; Wang \& Vasquez, 2012). Finally, learners also believed that they considered their blogs to be "a private place for them to describe, explore, and express their own ideas and feelings in the target language" (Wang \& Vasquez, 2012, 
p.12); in other words, they failed to fully utilise the interactive benefits provided by the technology, and essentially disregarded information shared among them or by their peers (Ducate \& Lomicka, 2008).

\section{Suggestions for Pedagogical Implications}

Based on the discussion in the previous sections, it could be concluded that Web 2.0 technology could provide more benefits than barriers. Nonetheless, it does not mean that the barriers should be swept away without taking them into considerations to ensure successful integration of Web 2.0 technology in ESL classroom that fully benefits the ESL learners in their learning process. Firstly, the support given by the administrations or managements of education institutions like universities and schools is vital and essential in order to make sure educators and learners fully optimise Web 2.0 technology in education. Then, training and technical supports are also needed to promote ESL educators and learners to utilise this intervention of ESL teaching and learning. Besides that, teachers also need to show good examples in using Web 2.0 tools in teaching, so that students could follow through the good examples displayed, hence encourage them to fully participate in doing the tasks provided.

Apart from that, teachers can promote the use of this Web 2.0 tools like the social networking sites by reassuring ESL learners to actively participate in the discussion, so that learners can be updated on the assignments, upcoming events, and other pedagogical information discussed. Good examples of writing can also be uploaded to offer learners an opportunity to share their thoughts about the examples provided. Furthermore, although scholars believed that it depends very much on the learners to have a better selfdiscipline, so they are not easily losing their focus by other features offered by the Web 2.0 tools while completing the tasks given, teachers could also act as a facilitator who monitors students' engagement and learning process. They need to remind students (especially young ones) to discipline themselves in completing the tasks given in a given time. Finally, to trigger students to be more disciplined, active and confident in partaking in the discussions held online, teachers can also play the role of a motivator and provide adequate motivation to students.

\section{Conclusions}

In conclusion, based on the reviews made on numerous studies in this article, it is evident that integrating Web 2.0 technology in ESL lessons does provide more benefits than barriers to the language learners. Using Web 2.0 technology in teaching and learning English help redefine the language classroom, for it allows students to have a more meaningful learning process that ultimately could also help enhance their English proficiency level. Furthermore, it is believed that Web 2.0 technology has played a significant role to support language teaching and learning due to its salient features of ICT. Undeniably, Web 2.0 technology which is popular among the young students nowadays is a motivational tool to be integrated in ESL education and various learning tasks, for many studies have been conducted on it, and have portrayed various benefits. These could be seen as an indicator that the utilisation of Web 2.0 technology in ESL classroom would be an effective approach in overcoming the difficulties faced by academicians in enhancing students' motivation to learn English language as well as improving their learning experience, and in the long run, increase their proficiency and mastery level. Hence, we should admit that Web 2.0 technology is discovering its way into 21st century language classrooms, and we need to ensure that students could gain the benefits of it to the maximum.

\section{References}

Ajjan, H., \& Hartshorne, R.( 2008). Investigating faculty decisions to adopt Web 2.0 technologies: Theory and empirical tests. Internet and Higher Education, 11(2): 71-80. htpps://10.1016/j.iheduc.2008.05.002.

Al-ali, S. (2014). Possible use of Instagram as a language mLearning tool. Issues and Trends in Educational Technology 2(2): 1-16. https://10.11139/cj.29.3.471-493.

Alexander, B., Levine, A. (2008). Web 2.0 storytelling. Emergence of a New Genre. EduCAUSE Review, 43 (6): 40-56. http://net.educause.edu/ir/library/pdf/ERM0865.pdf.

Bosch, T.E. (2009). Using online social networking for teaching and learning: Facebook use at the University of Cape Town. Communicatio 185-200. http://www.tandfonline.com/action/showCitFormats?doi=10.1080/02500160903250648.

Brady, K.P., Holcomb, L.B. \& Smith, B. V. (2010). The use of alternative social networking sites in higher educational settings : A case study of the e-learning benefits of Ning in education. Journal of Interactive Online Learning, 9(2): 151-170. https://10.1016/j.ijhcs.2012.04.002.

Ducate, C. L., \& Lomicka, L. L. (2008). Adventures in the blogosphere: From blog readers to blog writers. Computer Assisted Language Learning, 21(1), 9-28. 
Grandzol, C. J., \& Grandzol, J. R. (2010). Interaction in online courses: More is not always better. Online Journal of Distance Learning Administration, $13(2)$. http://www.westga.edu/ distance/ojdla/summer132/Grandzol_Grandzol132.pdf.

Greenhow, C., Robelia, B. \& Hughes, J.E. (2009). Learning, teaching, and scholarship in a digital age: Web 2.0 and classroom research: What path should we take now? Educational Researcher, 38(4): $246-259$. https://10.3102/0013189X09336671.

Grosseck, G. (2009). To use or not to use web 2.0 in higher education?. Procedia - Social and Behavioral Sciences; 1 (1): 478-482. http://10.1016/j.sbspro.2009.01.087.

Güzer, B., \& Caner, H. (2014). The past, present and future of blended learning: an in depth analysis of literature. Procedia - Social and Behavioral Sciences, 116, 4596-4603. http://dx.doi.org/10.1016/j.sbspro.2014.01.992

Harwati Hashim, Melor Md. Yunus, Mohamed Amin Embi \& Nor Azwa Mohamed Ozira. (2017). Mobileassisted language learning (MALL) for ESL learners: A review of affordances and constraints. Sains Humanika; 9: 1-5 (2017) 45-50. https://doi.org/10.11113/sh.v9n1-5.1175.

Jemima Tivaraju, Melor Md Yunus \& Jamaluddin Badusah. (2017). Learning English is fun via Kahoot: students' attitude, motivation and perceptions. Proceedings on Seminar on Transdisiplin Education (STEd2017), 218-229. https://sted2017.files.wordpress.com/2016/12/1-26-jemima-tivaraju-melor-mdyunus-jamaluddin-badusah.pdf

Lee, J. S. (2006). Exploring the relationship between electronic literacy and heritage language maintenance. Language Learning \& Technology, 10(2), 93-113.

Lomicka, L., \& Lord, G. 2016. Social networking and language learning. The Routledge Handbook of Language Learning Technology; Thorne 2010: 255-268. https://10.4324/9781315657899.

Manca, S., \& Ranieri, M. (2013). Is it a tool suitable for learning? A critical review of the literature on Facebook as a technology-enhanced learning environment. Journal of Computer Assisted Learning 29(6): 487-504. https://10.1111/jcal.12007.

McBride, K. (2009). Social-networking sites in foreign language classes: Opportunities for re-creation. The Next Generation: Social Networking and Online Collaboration in Foreign Language Learning; 8, 35-58. http://www.slu.edu/ kmcbrid8/McBride09_SNS.pdf.

Mcloughlin, C., \& Lee, M.J.W. (2007). Social software and participatory learning : Pedagogical choices with technology affordances in the Web 2.0 era introduction : Social trends and challenges. Ascilite 2007: 664675. htpps://10.1111/j.1083-6101.2007.00367.x.

Melor Md. Yunus, Hadi Salehi, \& Chun Chenzi. (2012). Integrating social networking tools into ESL writing classroom: Strengths and weaknesses. English Language Teaching 5(8): 42-48. http://dx.doi.org/10.5539/elt.v5n8p42.

Melor Md. Yunus, Hadi Salehi, Choo Hui Sun, Jessica Yong Phei Yen \& Lisa Kwan Su Li. (2011). Using Facebook groups in teaching ESL writing. Recent Researches in Chemistry, Biology, Enviroment and Culture: 75-80. http://www.wseas.us/e-library/conferences/2011/Montreux/COMICICBIO/COMICICBIO11.pdf.

Nakamaru, S. (2011). Making (and not making) connections with web 2.0 technology in the ESL composition classroom. National Council of Teachers of English; 38 (4): 377-390. http://www.ncte.org/library/NCTEFiles/Resources/Journals/TETYC/0384may2011/TETYC0384Making.pdf.

O'Reilly, T. (2005). What is Web 2.0? Electronic sources: Retrieved from O'Reilly: http://oreilly.com/pub/a/web2/archive/what-is-web-20.html?page=1

Richard, P. R., Cobo, P., Fortuny, J. M., \& Hohenwarter, M. (2008). Training teachers to manage problemsolving classes with computer support. In J. Luca, \& E. Weippl (Eds.), Proceedings of World Conference on Educational Multimedia, Hypermedia and Telecommunications (pp. 3520-3530). Chesapeake, VA: AACE.

Sadaf, A., Newby, T. J., \& Ertmer, P. A. (2012). Exploring pre-service teachers' beliefs about using web 2.0 technologies in K-12 classroom. Computers \& Education, 59(3), 937-945.

Siew Ming Thang, Rosniah Mustaffa, Fook Fei Wong, Noorizah Mohd. Noor, Najihah Mahmud, Hafizah Latif \& Mohd. Sallehhudin Abd. Aziz. (2013). A quantitative inquiry into the effects of blended learning on English language learning: the case of Malaysian undergraduates. International Education Studies; (6)6, 1-7. http://dx.doi.org/10.5539/ies.v6n6p1

Sturm, M., Kennell, T., McBride, R., \& Kelly, M. (2009). The pedagogical implications of Web 2.0. In M. Thomas (Ed.), Handbook of research on Web 2.0 and second language learning (pp. 367-384). Hershey, PA: Information Science Reference.

Suthiwartnarueput, T., \& Wasanasomsithi, P. (2012). Effects of using Facebook as a medium for discussions of English grammar and writing of low-intermediate EFL students. Electronic Journal of Foreign Language Teaching 9(2): 194-214. http://e-flt.nus.edu.sg/v9n22012/suthiwartnarueput.pdf. 
Termit, K., \& Ganisha, V. (2014). Teachers' Uptake on ICT Integration in Teaching and Learning. A Case of Malaysian Teachers. Pertanika Journal of Social Sciences \& Humanities; 22(4), 1163-1172.

Tess, P.A. (2013). The role of social media in higher education classes (real and virtual)-A literature review. Computers in Human Behavior 29(5): A60-A68. http://dx.doi.org/10.1016/j.chb.2012.12.032.

$\mathrm{Tu}, \mathrm{C}$., Blocher, M., \& Ntoruru, J. (2008). Integrate Web 2.0 technology to facilitate online professional community: EMI special editing experiences. Educational Media International, 45(4), 335-341. https://doi.org/10.1080/09523980802588634.

Wang, S., \& Vasquez, C. (2012). Web 2.0 and second language learning: What does the research tell us? CALICO Jounal; 29 (3): 412-430. http://camillavasquez.com/pdf/WangVasquez_Web2_CALICO.pdf.

Warschauer, M., \& Grimes, D. (2007). Audience, authorship, and artifact: The emergent semiotics of web 2.0. $\begin{array}{lllll}\text { Annual Review of Applied } & \text { Linguistics, } & \text { 27, } & 1-23 .\end{array}$ http://citeseerx.ist.psu.edu/viewdoc/download?doi=10.1.1.540.2850\&rep=rep1\&type=pdf.

Zhang, J. (2009). Toward a creative social web for learners and teachers. Educational Researcher, 38(4), 274-279. http://tccl.rit.albany.edu/papers/ERZhang09final.pdf. 